\title{
Kafkas Murahhaslarının İstanbul Seyahati ve Kafkasya Cephesi (1918)
}

\section{Mustafa SARI*}

Özet

1914 yılı Kasım ayı başlarında Osmanlı Devleti ve Rusya arasında Kafkasya Cephesi'nde savaş başladı ve ilerleyen yıllarda Rus orduları Anadolu'nun doğu kısmının neredeyse tamamını ele geçirdi. Osmanı Devleti aleyhine gelişen bu durum 1917 Mart ayında meydana gelen Rus ihtilali ile son buldu ve bu tarihten itibaren Kafkas Cephesi'nde gayr-i resmî bir mütareke durumuna girildi. Kasım 1917'de Bolşeviklerin iktidara gelmesinden sonra imzalanan Brest-Litovsk ve Erzincan mütarekeleri sonrasında Kafkas cephesindeki Rus birlikleri silah, mühimmat ve malzemelerini Ermeni ve Gürcü gruplara bırakarak çekildiler. Bu silahlarla kurulan Ermeni ve Gürcü milli orduları, Rusya'nın tahliye ettiği yerleri ele geçirmek için sadece Doğu Anadolu'da değil bütün Kafkasya cephesinde harekete geçtiler. Bu bölgelerde yaşayan Müslümanların yardım isteyebileceği tek güç ise Osmanlı Devleti'ydi. Bu nedenle, aralarında Azerbaycanlı lider Naki Keykurun Şeyhzamanlı ile Ahıskalı Müslüman liderlerden Ömer Faik Numanzâde'nin de bulunduğu Kafkasya murahhasları, Osmanlı Devleti'nden askerî ve siyasî yardım talebinde bulunmak için ŞubatMart 1918 tarihlerinde istanbul'a bir seyahat düzenledi. Kafkas heyetinin Osmanlı yetkilileri ile bir takım görüşmeleri neticesinde, 12 Şubat 1918 tarihinde Kafkas cephesinde başlayan Osmanlı ileri harekâtının Kafkasya'da Müslümanların yaşadığı bütün bölgeleri kapsamasına karar verildi. Azerbaycan'a yardım etmek için kurulan Kafkas islam Ordusu'nun temelleri de bu seyahat sırasında atıldı. Bu seyahat sonunda alına kararlar neticesinde Osmanlı birlikleri sadece Rusya'nın Anadolu'da ele geçirdiği toprakları değil, Elviye-i Selâse (Üç Sancak: Batum, Kars ve Ardahan) ve Ahıska-Ahılkelek gibi

"Yrd. Doç. Dr., Sakarya Üniversitesi, Fen-Edebiyat Fakültesi Tarih Bölümü, msari@sakarya.edu.tr.

Bu makale, Antalya'da 12-15 Kasım 2014 tarihleri arasında düzenlenen "Savaşan Devletlerin Tarihçilerinin Gözüyle 100. Yılında I. Dünya Savaşı" sempozyumunda sunulan bildirinin yeniden düzenlenmiş halidir. 
imparatorluğun 1914 sınırlarının dışında kalan bölgeleri de kontrol altına alarak Azerbaycan ve hatta Dağıstan'a girdi.

Bu çalışmada Kafkas murahhaslarının istanbul'a düzenlediği seyahat ve bu seyahatin cepheye etkileri, Başbakanlık Osmanlı Arşivi, Türk ve yabancı basın, o dönemde yaşayan insanların hatıratları ve ikinci el kaynaklar ele alınarak incelenecektir.

Anahtar Kelimeler: I. Dünya Savaşı, Kafkas cephesi, Kafkas murahhasları, Naki Keykurun Şeyhzamanlı, Ömer Faik Numanzâde

\section{The Caucasian Deputies' Visit to Istanbul and the Caucasusian Front}

(1918)

\section{Abstract}

The war broke out in early November 1914 between the Ottoman and Russian empires in the Caucasus, and that in the following years the Russian army occupied almost the entire Eastern Anatolia. This state of affairs only changed with the beginning of the Russian Revolution in March 1917, which brought about an undeclared truce on the Caucasian front. After the Bolsheviks came to power In November 1917, the armistices of Brest-Litovsk and of Erzincan were signed, and consequently the Russian troops began to withdraw from the Caucasian front. The departing Russian Army left their weapons, ammunition and other military supplies with the Armenian and Georgian forces, enabling them to set up their own national armies to seize control of the areas vacated by the Russian Army, not only in Eastern Anatolia but also in the Caucasus as a whole. For the Muslim population of the region, which were under the pressure of the Georgian and Armenian military formations, the only military and political power in the region to seek support from was the Ottoman Empire. Therefore, deputies from the South Caucasus, which included Naki Keykurun Şeyhzamanli of Azerbaijan and Omer Faik Numanzâde of Meskhetia (Ahiska) region, visited Istanbul between February and March in 1918 to seek military and political aid from the Porte. As a result of this initiative, the Turkish forward operation in Caucasian battlefields, which had begun on 12 February 1918, was reconfigured to include all areas inhabited by local Muslims. Furthermore, the foundations of an Ottoman army corps called the 'Islamic Army of the Caucasus', were laid during this visit. Due to these developments, the Ottoman Army not only re-captured the territories under Russian occupation but also took control of such districts as Elviye-i Selâse (The 
three sanjaks of Batum, Kars ve Ardahan) as well as Akhaltsikhe, Azerbaijan and Daghestan, which had been beyond Ottoman control before the war.

In this article, the Transcaucasian deputies' visit to the Porte and its effects on the Caucasian battlefields will be examined with the help of the archival materials obtained from the Ottoman Archives of the Turkish Prime Ministry, Ottoman and foreign media, the memoirs of key personalities of the era, and other secondary sources.

Keywords: World War I, the Caucasian Front, the Transcaucasian deputies, Naki Keykurun Şeyhzamanlı, Ömer Faik Numanzâde

\section{Giriş}

I. Dünya Savaşı’na büyük hedeflerle giren Osmanlı Devleti, Sarıkamış yenilgisini takip eden 1915 ve 1916 yılları içerisinde neredeyse bütün Doğu Anadolu ve Karadeniz kıyılarını kaybetti. Osmanlı Devleti'ni bu karamsar tablodan 1917 yılında meydana gelen Rus ihtilalleri kurtardı. 1917 yılında iktidara gelen Geçici Hükümet'in savaş çağrılarının aksine Bolşevikler iktidara geldikten sonra barış dekretini ilan ederek savaşı sonlandırmak istediler (Dokumentı Vneşney Politiki 12). Taraflar 1917 Aralık ayında Brest-Litovsk'ta masaya oturdular ve mütarekeyi imzaladılar (Kurat, 1967: 378). Brest-Litovsk Mütarekesi gereğince Osmanlı ve Rus komutanları Kafkasya Cephesi'nde 18 Aralık 1917'de Erzincan Mütarekesi'ni imzalayarak (Şahin 1998:169-171) Osmanlı Devleti ile Rusya arasında üç yıldır devam eden savaşı sonlandırdılar.

Erzincan Mütarekesi imzalandığında Maverâ-yı Kafkasya'yı* Gürcü, Azeri ve Ermeni temsilcilerinden oluşan Zakavkom (Maverâ-yı Kafkasya Komiserliği) adındaki bir idari birim yönetmekteydi ${ }^{1}$. Erzincan

* Bu çalışmada Maverâ-yı Kafkasya tabiri Kafkasya'nın güneyi için kullanılmaktadır. Fakat literatürde bu bölge için Transkafkasya, Zakavkaz, Cenubî Kafkasya, Güney Kafkasya, Ön Kafkas-ötesi, Kafkas-berisi, Kafkas-ardı vb. gibi farklı isimler de tercih edilmektedir.

${ }^{1} 1917$ Şubat Ihtilalinden sonra yeni Rus yönetimi 22 Mart 1917'de Maverâyı Kafkasya'yı idare etmesi için Ozakom (Maverâ-yı Kafkasya Özel Komitesi)'u kurmuştu. 1917 Ekim İhtilali'nden sonra ise merkezle uyuşamayan Maverâ-yı Kafkasya milletleri 28 Kasım 1917'de Ozakom yerine Zakavkom'u kurdular. Ozakom ve Zakavkom hakkında daha detaylı bilgi için bkz: Kurat, 1990: 459- 
Mütarekesi gereği Kafkas cephesindeki Rus birlikleri çekilmeye başlayınca (Dokumentı Vneşney Politiki 53-57), Ruslardan geriye kalan silah, mühimmat ve malzemelerin de yardımıyla kurulan Ermeni ve Gürcü ulusal orduları (Kurat 1990: 331), Rusya'nın tahliye ettiği yerleri kontrol altına almak için harekete geçtiler. Kendi milli ordularını kuramayan ve Gürcü ve Ermeni güçlerinin baskısı ile karşı karşıya kalan başta Azeriler ve diğer Türk ve Müslüman halkların Osmanlı Devleti'nden yardım talebinde bulunmaktan başka çareleri yoktu (Allen ve Muratoff 427).

Bu nedenle, Kafkasya'nın durumu hakkında malumat vermek ve Osmanlı Devleti'nden yardım istemek için Naki Keykurun Şeyhzamanlı́nın Azerbaycan'ı temsilen Ocak 1918 ortalarında İstanbul'a gönderilmesine karar verildi. Keykurun'a Osmanlı Devleti subaylarından olan ve I. Dünya Savaşı sırasında Ruslara esir düşen Süvari Teğmen Hüsamettin (Tugaç) Bey de eşlik etmekteydi. Naki Bey ve Hüsamettin Bey'in dışında, Ahıska'yı temsilen Ömer Faik Numanzâde, Acara'yı temsilen Hamşizâde Cemal Paşa'nın oğlu Celil Bey, ve Ahılkelek adına Efrahim Bey de temaslarda bulunmak için İstanbul'a gitmek üzere yola çıkmışlardı.

Kafkas murahhaslarının ${ }^{2}$ İstanbul seyahati, buradaki temasları ve bu seyahatin Kafkasya cephesine tesirleri bugüne kadar müstakil bir çalışmaya konu olmamıştır. Qiyas Şükürov'un “Cumhuriyetin Kuruluş Devrinde Azerbaycan'da İstiklâl ve İlhak Tartışmaları" adlı makalesinde bu seyahat ilhak-bağımsızlık tartışmaları çerçevesinde ele alınmıştır. Vasif Qafarov'un "Türkiye-Rusya Münasebetlerinde Azerbaycan Meselesi (1917-1922)" kitabında ve Mehman Süleymanov'un "Kafkas İslam Ordusu'nun Kuruluşu, Hazırlık ve Seferberlik Durumu" adlı

462; Kazemzadeh 34-35, 57-58; Şahin 2002: 30-42, 114-123; Dokumentı i Materyalı Po Vneşney Zakavkazya i Gruzii 7-8.

2 Burada bir hususu belirtmekte fayda vardır. Kafkasya'dan gelen murahhaslar görüldüğü üzere ayrı ayrı ve birbirlerinden bağımsız olarak yola çıkmışlardır. Murahhaslar ilerleyen günlerde birleşmelerine rağmen İstanbul'a sadece Naki ve Ömer Faik Beyler ulaşabilecektir. Bu nedenle Kafkasya'dan İstanbul'a gelen bu murahhaslara heyet denilip denilmeyeceği tartışmaya açıktır. Fakat Naki Keykurun'un Gence Milli Komitesi tarafından "murahhas heyet" şeklinde adlandırıldığı için çalışmanın bazı yerlerinde adı geçen kişiler için "Kafkas murahhas heyeti" tabiri de tercih edilmiştir. 
makalesinde Kafkas murahhaslarının i̇stanbul seyahatine yer verilmesine rağmen konu dar kapsamda ele alınmıştır. Dolayısıyla bu çalışmada Kafkas murahhaslarının ìstanbul seyahatleri, oradaki faaliyetleri ve geri dönüşleri detaylı bir şekilde incelenmeye çalışılmıştır.

Bu çalışma için en önemli kaynak bazı abartılı ifadeler ihtiva etse de Naki Keykurun'un hatıratıdır. "Azerbaycan İstiklâl Mücadelesinden Hatıralar" ismini taşıyan bu eser, Kafkas murahhaslarının İstanbul seyahati hakkında detaylı bilgiler içermektedir. Ayrıca bu seyahat sırasında murahhasların yanında bulunan Hüsamettin Tugaç'ın hatıratı da bu çalışma açısından önem taşımaktadır. Bu hatıratların dışında diğer bir Kafkas murahhası Ömer Faik Numanzâde'nin de hatıratı yayınlanmasına rağmen bu hatıratın ancak 1905 yılına kadar gelmesi, çalışma açısından büyük kayıptır. Bu seyahat ile alakalı Başbakanlık Osmanlı Arşivi'nde de vesikalar bulunmaktadır. Bunun dışında İstanbul basını ve diğer araştırma inceleme eserler de çalışmada kullanıımıştır.

\section{Kafkas Murahhaslarının Yolculuğu}

Azerbaycanlılar, 1917 Mart ihtilalinden sonra millî bir kimlik oluşturmaya çalıştılar. Bu amaçla Azerbaycan Türklerinin en önemli iki teşkilatı olan Gence merkezli Türk Adem-i Merkeziyet Fırkası ile Bakû merkezli Müsavat Fırkası Haziran 1917' de birleşti ve bölgedeki Türkler tek çatı altında çalışmaya başladı (Mehmetzâde 78-81; Swietochowski 129). Fakat Kasım ayında gerçekleşen ihtilalden sonra Bolşevikler ve silahlı Ermeni güçleri (ki bunların da büyük bir çoğunluğu Bolşevikti) özellikle Bakû üzerindeki tazyiklerini artırdılar. Bunun dışında Tiflis'te bulunan İngiliz ve Fransız misyonları ise bölgenin Bolşevik Rusya ve Osmanlı Devleti tarafından kontrol edilmesini önlemek için Ermeni ve Gürcü toplumlarını organize etmeye çalışmaktaydılar. ${ }^{3}$

Gence Milli Komitesi ${ }^{4}$ bu güç durumdan kurtulmak için Ocak 1918 'de Gence'de Azeri partilerinin katıldığı bir toplantı düzenledi. Komite Başkanı Nesib Bey Yusufbeyli, "Muhakkak büyük yardıma

\footnotetext{
${ }^{3}$ Rus ihtilalleri ile oluşan bu durumun ayrıntısı için bkz: Keykurun 74-82.

4 I. Dünya Savaşı yıllarında Milli Komite'nin Nesib Bey Yusufbeyli başkanlığında İcra Heyeti oluşturulmuştu. Nesib Bey aynı zamanda Azerbaycan Adem-i Merkeziyet Fırkası'nın da lideriydi (Keykurun 48-52).
} 
ihtiyaç vardır ve bu yardımı da bize ancak Osmanlı Imparatorluğu yapabilir. Burada karar alalım ve Osmanlı Imparatorluğu nezdinde bir murahhas heyet gönderelim. Türkiye'den askerî yardım isteyelim" sözleriyle Osmanlı Devleti'nden yardım istenilmesi konusu tartışmaya açtı. Toplantıya katılan diğer parti liderleri de Osmanlı Devleti'nden askerî yardım istemek konusunda birleştiler. Sonunda Osmanlı Devleti nezdinde "murahhas heyet" gönderilmesi için Milli Komite'ye tam yetki verildi. Nesib Bey ise "murahhas heyet" olarak Naki Keykurun'u görevlendirdi (Keykurun 83-84). Naki Keykurun'a Osmanlı Devleti subaylarından olup Ruslara esir düşen ve o sıralarda Gence'de bulunan Hüsamettin Bey de eşlik edecekti. Hüsamettin Bey bir müddetten beri Gence'de Azerileri teşkilatlandırmaktaydı (Tugaç 185196).

Naki Keykurun ve Hüsamettin Beyler Ocak 1918'de Gence'den trenle hareket ederek Tiflis'e geldiler ve Cemiyet-i Hayriye'ye gittiler (Keykurun 86). Amacı başta Azeriler olmak üzere bütün Kafkas Müslümanlarına yardım etmek olan Cemiyet-i Hayriye zengin Azeriler tarafından kurulan bir cemiyetti ve Kafkasya'nın birçok yerinde olduğu gibi Tiflis ve Batum'da da şubeleri bulunmaktaydı ${ }^{5}$. Naki Keykurun ve Hüsamettin Beyler Tiflis Cemiyet-i Hayriye Reisi Doktor Hüsrev Bey'le görüşerek maksatlarını anlattılar (Keykurun 86). Hüsrev Bey, aynı zamanda Maverâ-yı Kafkasya Seymi'nde Azerbaycan üyesiydi ve onlara Trabzon bölgesinde Müslümanlarla Rumlar arasında meydana gelen çatışmaları durdurmak için Azerbaycan adına bir arabulucu heyet olarak bölgede faaliyette bulunabileceklerine dair belgeler hazırladı. Seym hükümeti de bunu onayladı. Naki ve Hüsamettin Beyler bu belgeleri aldıktan sonra (Tugaç 197) ${ }^{6}$ Batum'a ulaştılar.

${ }^{5}$ Cemiyet-i Hayriye hakkında ayrıntılı bilgi için bkz: Aslan 2000.

${ }^{6}$ Seyahatin bu kısmını Naki Bey hatıratında şu şekilde anlatmaktadır: “Cemiyet Reisi merhum Doktor Hüsrev Beyle görüşerek maksadımızı anlattık. Bize Cemiyet-i Hayriye mensubu olduğumuza dair birer hüviyet verdi. Bu vesikalar ile bütün Kafkasya cephesini dolaşmak salahiyetimiz vardı. Vesikalarımızı aldıktan sonra Hüsrev Bey'e veda edip Batum'a hareket etmek üzere istasyona geldik" (Keykurun 86). Görüldüğü üzere Naki Keykurun Seym üyesi olduklarına dair bir belge aldıklarından ve bunun Seym tarafından onaylandığından bahsetmemektedir. Fakat Hüsamettin Tugaç hatıratının 
Batum Rus askerlerinin varlığı nedeniyle oldukça kalabalıktı. Burada Batum Cemiyet-i Hayriye reisi Doktor Mahmut Bey'in yanına gittiler. Maksatlarını anlattıktan sonra kendilerinin güvenli bir şekilde Osmanlı Devleti topraklarına geçirilmelerini rica ettiler. Doktorun evine gittiklerinde ise Ahıskalı Ömer Faik Numanzâde Bey'le karşılaştılar (Keykurun 86-87). Yukarda bahsedildiği gibi Ömer Faik Bey de İstanbul'a giderek Osmanlı Devleti'nden Kafkasya Müslümanları adına yardım istemeyi düşünüyordu. Ömer Faik Bey, Tiflis'ten 3 Şubat 1918 'de hareket etmişti (BOA, DH.EUM.5.Şb., 55/26, lef: 3). Bu arada Acaralıların önde gelen simalarından Hamşizâde Cemal Paşa, oğlu Celil Bey'i Acaralılar adına Osmanlı hükümetine göndermek için Kafkas murahhas heyetine katmak istiyordu. Ayrıca Efrahim Bey adında birisi de Ahılkelek adına aynı maksatla İstanbul'a gitmek istediğini murahhaslara bildirdi (Tugaç 158-159). Böylece Kafkas murahhaslarının sayısı beş kişiye çıktı.

Murahhaslar Doktor Mahmut Bey'in evindeyken Giresunlu bir Rum aileye mensup, Batum'da tütün ticareti yapan Bünyadoğlu adında birisi eve geldi. Bünyadoğlu'nun Doktor Mahmut Bey'in evine gelmesinin nedeni Trabzon'daki Türk çetelerinin Rum köylerini basmaları ve mallarını almalarıydı. Bunu önlemek için Batum'dan bir heyet teşkil etmişlerdi. Bünyadoğlu, Cemiyet-i Hayriye mensuplarından iki kişinin Trabzon'a gidecek Rum heyetine katılmalarını istiyordu (Keykurun 87). Mahmut Bey Bünyadoğlu’na Hüsamettin ve Naki Beylerin aynı mesele için Azerbaycan tarafından gönderildiklerini izah etti ve Tiflis'ten alınan belgeleri gösterdi. Bunun üzerine Bünyadoğlu durumu kabul etti (Tugaç 198). Böylece İstanbul yolunda bir adım daha atılmış oldu çünkü Trabzon bu sıralarda henüz yeniden Osmanlı kontrolü altına girmemişti ${ }^{7}$.

Ömer Faik Bey ve yanındakiler kara yoluyla Trabzon'a geçerlerken (Tugaç 199), Naki ve Hüsamettin Beyler Batum'dan Rumlarla birlikte vapura bindiler. Naki ve Hüsamettin Beyler Trabzon'a geldiklerinde Rum heyetiyle birlikte doğruca Metropolithane'ye gittiler. Burada Metropolit de dâhil bir takım kişilerin konuşmalarından sonra Naki

ilerleyen sayfalarında kendilerini etraftakilere Cemiyet-i Hayriye mensubu olarak tanıttıklarını ifade edecektir (Tugaç 202).

7 Trabzon 24 Şubat'ta Osmanlı ordusu tarafından ele geçirilecekti. Bkz. Şahin 2002: 451. 
Bey söz olarak Rusya'da iç karışıklığın hakim olduğunu, her milletin merkezden ayrılıp müstakil devlet kurma çabasında olduğunu, bu nedenle Rumların Osmanlı Devleti ve ordusuyla temasa geçmesi gerektiğini belirtti. Fakat bu sözler orada bulunanların hoşuna gitmedi.

Ertesi gün Rum heyetiyle birlikte civarda incelemelerde bulunuldu. Daha sonra Naki ve Hüsamettin Beyler heyetten ayrılarak Tirebolu'ya geldiler. Burada Batum'dan itibaren kendilerinden ayrı seyahat eden Ömer Faik Bey, Celil ve Efrahim Beyler ile karşılaştılar. Naki Keykurun ile Ömer Faik Beyler birbirlerini daha ciddi tanıma imkânını buldular. Fakat bu sırada aralarında ilk kez tartışma çıktı. Çünkü Naki Bey Osmanlı Devleti'nin yardımı ile Azerbaycan'ın bağımsızığına kavuşmasını isterken, Ömer Faik Bey Osmanlı Devleti'nin Kafkasya'yı ilhak etmesini istiyordu. Ömer Faik Bey aynı zamanda Naki Bey'in bu fikirlerini Osmanlı başkentinde söylemesi durumunda Osmanlı yetkilileri tarafından tutuklanacağını da iddia ediyordu (Keykurun 8793).

Kafkas murahhaslarını Tirebolu'da 36. Fırka Komutanı Albay Kazım (Özalp) Bey karşıladı ve III. Ordu Komutanı Ferik Mehmed Vehib (Kaçi) Paşa'ya geldiklerini bildirdi. Vehib Paşa da murahhasların hemen yanına, Suşehri'ne gönderilmesini istedi. Daha sonra Kafkas murahhasları bir gambota binerek ((Tugaç 207)) 15 Şubat 1918'de Giresun'a geldiler (BOA, DH.ŞFR, 578/23).

Giresun'dan sonra birkaç günlük yolculuğun ardından 19 Şubat'ta Osmanlı Kafkas Cephesi karargâhının bulunduğu Suşehri'ne geldiler (BOA, DH.EUM.5.Şb., 55/26, lef: 3) ${ }^{8}$. III. Ordu Komutanı Vehib Paşa ile Hüsamettin Bey daha önceden tanışıyorlardı. Bu nedenle kendisi Kafkas murahhaslarını Vehib Paşa'ya takdim etti. Ordunun Kurmay Başkanı Ömer Lütfi ve Harekât Şubesi Müdürü Hüsrev Beylerin de hazır olduğu bir görüşmeden sonra Vehib Paşa, Hüsamettin Bey'den Kafkasya'nın durumuyla alakalı bir rapor hazırlamasını istedi. Hüsamettin Bey de hemen raporunu tamamladı ve Paşa'ya sundu. Raporda özetle bölgede Rus ordusunun dağıldığı; Rusların geri çekilirken çok miktarda yiyecek, giyecek, harp araç ve gereçleri arkalarında bıraktıkları ve bunların Gürcü ve Ermeni güçlerinin eline

${ }^{8}$ Hüsamettin Bey hatıratında Suşehri'ne Şubat 1918 başında geldiğini belirtse de (Tugaç 214) görüldüğü üzere Osmanlı Arşiv kayıtları Şubat’ın sonlarını göstermektedir. 
geçtiği; Gürcü ve Ermeni toplumlarının Tiflis'te bulunan İngiliz-Fransız misyonlarının yardımı ile kendi ordularını kurarlarken, Müslümanların ordularının olmadığı ve dolayısıyla Rus askerlerinin çekildikleri yerlerde özellikle silahlı Ermeni güçlerinin taarruzları sonucunda bir tek Müslümanın bile kalmama ihtimalinin olduğu; bu nedenle Gence Millî Komitesi'nin ve siyasi partilerin aldıkları karar üzerine Osmanlı ordusunu davet için murahhas gönderdikleri bilgileri vardı. Hüsamettin Bey, raporuna ayrıca Osmanlı ordusunun ileri harekâta vakit kaybetmeksizin geçmesi gerektiği de (Tugaç 209-211). Bu bilgiler o zamana kadar Kafkas cephesi hakkında fazla malumatı olmayan Osmanlı ordusu için çok değerliydi.

Aslında Osmanlı ordusu Hüsamettin Bey ile Kafkas murahhaslarının Suşehri'ne gelmesinden bir süre önce, 12 Şubat'ta harekâta başlamıştı. İlk baştaki amacı silahlı Ermeni güçlerinin Doğu Anadolu'da özellikle sivil halka karşı gerçekleştirdikleri saldırılara son vermek olan ileri harekât, III. Ordu birlikleri tarafından üç ana koldan yürütülmekteydi (NA, WO, 106/6239; FO, 3371/ 3335, 130177; Belen 151-152). Harekâtın başlamasından bir gün sonra Erzincan'a giren Osmanlı birlikleri (Kafkas Cephesi 446; Atak 86; Karabekir 2009: 488), Hüsamettin Bey ve Kafkas murahhaslarının verdiği malumatların da yardımıyla ilerleyerek 21 Şubat'ta Gümüşhane ve Torul'u (Şahin 2002: 450), 22 Şubat'ta Mamahatun'u (Çakmak 268), 24 Şubat'ta Trabzon'u (Ati, 25 Şubat 1334/1918, n. 56, s. 1; ikdam, 25 Şubat 1334/1918, n. 7559, s. 1), 25 Şubat'ta Aşkale'yi ve 26 Şubat'ta da Yeniköy'ü geri almışlardı (Belen 153; Karabekir 2009: 490).

Hüsamettin Bey, hatıratında bahsettiğine göre raporunu Vehib Paşa'ya sunduktan sonra Paşa, o gece sabaha kadar Enver Paşa'yla telgraf başında yazışmışlardı (Tugaç 212-213). Bundan sonradır ki Osmanlı yetkilileri, 1914 sınırı ötesinde de bir takım planlamalar yapmaya başladılar. Nitekim Brest-Litovsk görüşmelerinde o güne kadar gündeme gelmeyen Elviye-i Selâse'nin durumuyla ilgili, 24 Şubat'ta Zeki Paşa ${ }^{9}$ vasıtasıyla 1878 sınırlarını da aşacak şekilde yeni düzenlemelerin yapılmasının Almanlardan istenilmesi (Kılıç 343) tesadüfî değildi.

9 Zeki Paşa, Berlin Askerî Ataşesi olup, Brest-Litovsk Müzakereleri'ne Osmanlı Devleti'nin temsilcisi olarak katılmıştır. Bkz. Kurat, 1967: 378; Kılıç 77-78. 
Kafkasya meselelerinde savaş başından beri hassasiyet gösteren Enver Paşa, Vehib Paşa'ya Kafkas murahhaslarının bir an önce İstanbul'a gönderilmesini emretmişti (Keykurun 94). Çünkü işgal altındaki Doğu Anadolu ve Kafkasya hakkındaki bilgileri birinci ağızdan duymak istiyordu. Vehib Paşa ise Hüsamettin Bey'i karargâhta faydalı olacağını düşündüğü için alıkoydu (Tugaç 213). Bunun dışında Celil ve Efrahim Beyler de İstanbul'a kadar gitmekten vazgeçtiler. Bunun üzerine Kafkas murahhas heyetinde sadece Naki ve Ömer Faik Beyler kaldı.

Enver Paşa'dan talimatı alan Vehib Paşa tarafında yola çıkarılan murahhaslar, 2 Mart 1918'de isstanbul'a ulaştılar (Tasvir-i Efkâr, 4 Mart 1334/1918, n. 2383, s. 1; Vakit, 3 Mart 1334/1918, n. 133, s. 2).

Kafkas murahhasları henüz yoldayken, Ömer Faik Bey Sadrazam Talat Paşa'ya ve Harbiye Nâzırı Enver Paşa'ya hitaben bir mektup göndermişti. Kafkasya hakkında oldukça detaylı bilgilere sahip olan ve Osmanlı devlet ricali arasında heyecan oluşturan mektup şu şekildedir:

“Kafkas'ın muhtelif Müslüman yerlerinden bir murahhas hey'eti Şubat 3'de Tiflis'ten çıkıp 19'da Suşehri'ne gelerek, Vehib Paşa ile görüştükten sonra yoldaşlarım avdet edip ben İstanbul'a geleceğim. Şubat 5'de Tiflis'te Müslüman, Ermeni ve Gürcü a'zasından ibaret Meclis-i Müessesan açılmakla Kafkas, Bolşevik hükümetinden tamamıyla ayrılmıştır. Kafkas hükümetinin ise ancak resmî adı var. Müslüman, Gürcü, Ermeni vilâyetleri fi'len ayrılıp kendi komiteleri vâsıtasıyla idare olunmaktadır. Bununla beraber Kafkas büyük bir anarşi içindedir. Bakû ve Gence vilâyetleri tamamen, Kars, Revan ve Batum vilâyetleri kısmen Müslümanlar elindedir.

Kars ve Revan şehirleri halen Ermeniler, Batum Hıristiyan Gürcülerdedir. Kafkas Hükûmeti sulh müzâkeresi için bir ay müddet istemesine başka bahane getiriyorsa da asıl maksat Ermeni, Gürcü, Rum, Oset ve Kafkasyalı Ruslardan birer kolordu ve fırka teşkil edip bu müddette hududa göndermek ve bu yol ile sulh müzâkeresine bir te'sir vermektir. Tiflis'te yüzden fazla bulunan İngiliz ve Fransız zabit ve mühendisleri Gürcü paralar ve şahsî yardımlarıyla taze yerli kolorduların sür'atle itmamına fedâkârâne çalışıyorlar. İngilizlerin fikri Bağdat'la Van arasında Ermenilerle büsbütün Kafkas'ı ele geçirmek veya bu yolda bir nümâyiş gösterip Ermenileri aldatmakla Osmanlı ordularını Kafkas hudutlarında tutmaktır. İngilizler, Kafkas Hükûmeti 
ve ahâlîsini Osmanlı'nın hudutta büyük kuvveti olmadığına ve hududu muhafaza etmenin çok kolay olduğuna inandırmaktadırlar*. Bu ümide göredir ki bütün Ermeni milleti, hatta büyük piskopos, mu'allim ve ediplerin hepsi kendi oğul ve kızlarıyla Ermeni ordusuna girmekle beraber gayet mü'essirâne makaleler yazıp bütün milleti silaha da'vet ediyorlar. Bununla beraber Ermeniler arkalarını tehdit eden Müslümanlardan ziyade endişededirler. Müslümanlarla Ermeniler arasındaki gerginlik ise son dereceyi bulmuştur. Fakat Müslümanlar Osmanlı'nın maksat ve planını gözleyip imdilik sabr etmektedir. Müslümanlar Tiflis-Bakû demiryoluyla giden Rus askerlerinden zorla otuz bin tüfenk, yigirmi dört top, yigirmi makineli tüfenk alarak yolları kestiklerinde Rus askeri imdi ancak Batum deniz yoluyla gidiyor. Rus askeri on, on beş güne kadar tamamıyla Kafkas'dan çekilip kurtulur. Hiçbir Rus Kafkas'ta kalmak istemiyor. Bu anda yetmiş, seksen bin silahlı Müslüman yardıma hazır. Eğer Kafkas'a tezlikle silah ve sivil elbiseli zabitler gönderilirse bu kuvveti yüz elli, iki yüz bine çatdırmak kolay. Ermenilerin büyük fedakârlık göstermeleriyle beraber şimdilik ancak kırk, elli bin kuvveti var. Tezlikle Kafkas'a girilmeyip vakit verilirse kuvvetlerini yüz bine çıkarabilirler. Gürcü kolordusu ancak kendi yerlerini muhafazaya çalışabilecektir. Gürcülerin Osmanlı'ya karşı asker göndermemeleri dostluklarından değil, korkularındandır. Rusya'nın vaz'iyet-i siyasiyesi değiştiği anda Gürcülerin de Osmanlı'ya karşı olan dostlukları düşmanlığa çevrilmiştir. Ve son aylarda müttefikleri müktezası olarak Osmanlı ve Kafkas Müslümanları aleyhinde Ermenilerle tedâfü-i ittifaka girmişlerdir. Ermeni ve Gürcü kolorduları sür'atle teşkil olunmakla beraber itmamı en az bir aya mütevakkıftır. Buna mukâbil Müslümanlar da boş oturmayıp Osmanlı esir zabit ve küçük zabitleri vasıtasıyla milis kıt'aatı ihzar etmektedir. Biz inanıyoruz ki Osmanlı mukadderatını ellerine alanlar hükümet binasını sağlam duran temeli üstüne kurmak için en mühim uzv olan Kafkas'la İran Azerbaycanı'nı birleştirmeye müsa'it olan şu fırsatı elden çıkarmazlar. Ve bu ulu millî gayeyi hiçbir hususî fikir ve ihtiyata kurban etmezler" (BOA, DH.EUM.5.Şb., 55/26, lef: 3).

Mektupta görüldüğü üzere Kafkasya'da otorite boşluğunun bulunduğu ve İngilizlerin bu boşluğu değerlendirerek büyük Ermenistan kurmak niyetinde olduğu Osmanlı Devleti'nin tarihi bir

Bu cümlenin orijinali şu şekildedir: “Ingilizlerin Kafkas Hükûmeti ve ahâlîsini inandırıyorlar ki Osmanlı'nın hudutta büyük kuvveti yoktur ve hududu muhafaza etmek çok kolaydır". 
fırsatı yakaladığı ve elini çabuk tutarak Kafkas Müslümanlarını da kullanarak bu bölgeleri askeri yolla alması gerektiği belirtiliyordu.

Kafkasya hakkında oldukça önemli malumat içeren bu mektup, ilk önce Karahisar-ı Şarki Mutasarrıflığı'na verilerek, mutasarrıflık tarafından Osmanlı Sadareti'ne, Harbiye Nezareti'ne, VI. Ordu Komutanı Halil Paşa'ya ve Ağaoğlu Ahmed Bey'e şifre ile gönderilmesi istenmişti (BOA, DH.ŞFR, 578/72). Fakat Mutasarrıfık tarafından Sivas Vilayeti'ne bu mektuplar şifreli telgrafla değil posta yoluyla gönderilince, Osmanlı hükümeti bu mektupların içeriğinden ancak 2 Mart tarihinde haberdar olabildi. Asılları ise 7 Mart'ta Sivas'tan postaya verildi (BOA, DH.ŞFR, 579/92). Mektup İstanbul'a ulaştığında Kafkas murahhasları zaten şehirde bulunuyordu.

Kafkas murahhas heyeti İstanbul'a ulaştığı sırada Kafkasya'da bazı önemli gelişmeler yaşanmıştı. Osmanlı Devleti, Ocak 1918 tarihinden itibaren Maverâ-yı Kafkasya Komiserliği ile barış görüşmelerini gerçekleştirmek istiyordu. Komiserlik buna ilk başlarda pek sıcak bakmamasına rağmen 12 Şubat'ta başlayan Osmanlı ileri harekâtının Osmanlı Devleti açısından başarılı bir şekilde devam etmesi üzerine 23 Şubat'ta Seym adında bir kanun yapıcı meclisi hayata geçirmiş ve Osmanlı Devleti'nin barış teklifini kabul etmişti. Böylece taraflar Mart ayı başlarında Trabzon'da bir konferans yapılması konusunda mutabık kaldılar. ${ }^{10}$

Bu sırada Kafkasya açısından en önemli gelişme hiç şüphesiz ki 3 Mart 1918'de imzalanan Brest-Litovsk Antlaşması oldu. Elviye-i Selâse ile birlikte Kafkasya'nın da kapılarını Osmanlı Devleti'ne açan bu antlaşmanın dördündü maddesinin ikinci ve üçüncü bendlerine göre Rusya Doğu Anadolu'da işgal ettiği yerleri tahliye edecek; Kars, Ardahan ve Batum sancakları derhal Rusya tarafından boşaltılacak ve Rusya bölgede devletlerarası hukuka göre oluşacak yeni yönetime karışmayacak, ayrıca bölge ahalisi komşu ülkeler ve özellikle Osmanlı Devleti ile uyuşarak bu yeni yönetim tarzını belirlemede serbest olacaktı (Düstur, 407-412; Meclis-i Mebusan Zabıt Cerideleri, 418-420; The Manchester Guardian, 5 Mart 1918, s. 5; The Times, 5 Mart 1918, n. 41729, s. 6).

${ }^{10}$ Daha detaylı bilgi için bkz. Şahin 2002: 224-244. 
Brest-Litovsk Antlaşması sadece Elviye-i Selâse'deki değil Kafkasya'nın diğer bölgelerindeki Türk ve Müslüman toplumları için de cesaretlendirici olmuştu. Fakat Brest-Litovsk Antlaşmasını imzalamak yeterli olmayacaktı. Bu antlaşmanın hükümlerini Maverâ-yı Kafkasya Seym'ine de kabul ettirmek gerekecekti.

\section{Kafkas Murahhaslarının İstanbul'daki Çalışmaları}

Naki Bey Ocak 1918 ortalarında Gence'den, Ömer Faik Bey ise Şubat başlarında Tiflis'ten İstanbul'a gitmek için yola çıkmışlar ve yaklaşık 11,5 ay yolculuktan sonra İstanbul'a ulaşabilmişlerdi. Kafkas murahhasları devletin misafiri olarak Pera Palas oteline yerleştirildiler. Bu sırada ikili arasında ilhak ve bağımsızlık konusundaki tartışma yeniden alevlendi. Naki Bey, ilhak düşüncesini benimseyen Ömer Faik Bey'e Osmanlı yetkilileri karşısında Ahıska hakkında konuşmasını Gürcistan'dan öteye geçmemesini tembih etti.

İstanbul'a vardıktan sonra Naki Bey ve Ömer Faik Bey aynı gün Bâb-ı Ali tarafından davet edildiler ve burada ilk görüşmelerini Sadrazam Talat Paşa ile yaptılar. Enver Paşa ve Meclis-i Mebusan Reisi Halil (Menteşe) Bey'in de katıldığı toplantıda, Naki Bey öncelikle Gence Milli Komitesi'nden aldığı itimatnameyi Talat Paşa'ya verdi. Naki Bey daha sonra Kafkasya'nın özellikle de Azerbaycan'ın durumu hakkında bilgiler vererek "Azerbaycan halkı sizden yardım bekliyor. Milletimiz müstakil olmaya azmetmiştir. Siz kardeş elinizi bize uzatınız, bize yardım ediniz. Müstakil olalım. Siz bizi çekip yıkmayınız, ayakta duralım. Bize büyük askerî kuvvet göndermeyiniz. Bize askeri ögretmenler ve çavuş kadrosu gönderiniz" sözleriyle Azerbaycan'ın bağımsızlığı için Osmanlı Devleti'nden yardım istedi. Naki Bey'in açıklamaları Osmanlı devlet ricalinin hoşuna gitmişti. Naki Bey'den sonra söz alan Ömer Faik Bey ise şu şekilde konuşmuştu: "Azerbaycan halkı Türklüklerini bihakkın idrak etmiş bir millettir, istiklale layıktırlar. Kuvvetli bir edebiyata maliktirler. Ancak benim ricam şu: Bizim kazamı Ahıska tam Türkiye hududundadır. Orasının ilhakını istiyorum." Talat Paşa ise "Emin olun, Paşa Hazretleri bu arzunuzu yerine getirir. Yarın teşkilatı kurmağa başlayacağız." şeklinde Ömer Faik Bey'e karşılık verdi. Naki Keykurun ertesi gün Harbiye Nezareti'nde Enver Paşa ile görüştü. Paşa, Naki Bey'e Kafkas İslâm Ordusu teşkilatının oluşturulmasına yönelik çalışmaların başlatıldığını, 
bir üst rütbe ile subay kaydedileceğini ve bunun için bir komisyon kurulduğunu anlattı ve Naki Bey'in de komisyonda bulunmasını istedi. Enver Paşa kurulacak olan Kafkas İslam Ordusu'na komutan olarak Şehzade Ömer Faruk'u düşünüyordu. Enver Paşa Şehzâde'yi de yanında getirmişti ve onu Naki Bey'le tanıştırdı (Keykurun 96-100) ${ }^{11}$.

İstanbul'da kaldığı müddetçe her gün kurulacak İslam Ordusu ile ilgili komisyonun çalışmalarına katılan Naki Bey hemen her gün Enver Paşa ile de görüşmeye devam etti. Naki Bey bir görüşmesinde Enver Paşa'ya şu sözleri söylemiştir: "Paşam, sizin ile açık konuşmak istiyorum. Biz Kafkasya Türkleri iki kuvvete inanıyoruz. Yukarıda Allah, aşağıda Enver. Duyduğuma göre sizin Nuri adında bir paşa kardeşiniz vardır. Sizden rica ediyorum. Kafkasya'ya gidecek askeri teşkilatın başına Nuri Paşayı tayin ediniz. Paşam, sizin Kafkasya'da gidecek askerlere kumandan tayin ettiğiniz Prensi her akşam Pera Palas otelinin salonunda içki içip dans ederken görüyorum. Kafkasya'da böyle hallerden hoşlanmazlar." Bunun üzerine Enver Paşa, İslam Ordusu Komutanı olarak Nuri Paşa'nın atandığını söyledi. Enver Paşa aynı zamanda İslam Ordusu askerlerinin de içki içmeyenlerden seçilmesini istedi. Naki Bey ile Nuri Paşa İslam Ordusu'nu kurma çalışmalarını artık birlikte yürütmeye başladılar (Keykurun 100-101) ${ }^{12}$.

${ }^{11}$ Şehzade Ömer Faruk o sıralarda henüz 20 yaşında genç birisi olmasına rağmen Avusturya ve Almanya'da oldukça kaliteli eğitim gören ender şehzadelerdendi. Hatta ekber ve erşed sisteminden dolayı padişah olması ihtimal dâhilinde olmamasına rağmen aldığı bu eğitim sayesinde, bazı çevreler onu ileride padişah yapmayı düşünmekteydi. Şehzade Ömer Faruk Almanya'dayken I. Dünya Savaşı'na da katılarak Verdun cephesinde savaşmıştı (Kırpık 114-115, 118).

12 Burada şu bilgiyi de hatırlatmak fayda vardır. Kazım Karabekir Paşa hatıratında belirttiğine göre Enver Paşa, kendisine 23 Şubat 1918'de Kafkas İslam Ordusu komutanlığını teklif etmişti. Fakat o sıralarda albay olan Kazım Karabekir, bu teklifi Erzurum'un kurtuluşu savaşında olduğu gerekçesiyle kabul etmemişti. Erzurum kurtulduktan sonra Kazım Karabekir bu göreve talip olsa da Enver Paşa kardeşi Nuri Paşa'yı bu göreve atadığını isterse kendisinin Kuzey Kafkasya'da teşkil edilecek ordunun başına geçirebileceğini söylemiştir. Kazım Karabekir ilk başta bunu kabul etmesine rağmen, Fahri Ferik Nuri Paşa'nın komutası altına gireceğini öğrenince bu vazifeyi de kabul etmemiştir (Karabekir 1990: 272-273, 300-303). Enver Paşa'nın daha henüz 23 Şubat gibi Kafkasya'da bir teşkilatın kurulmasını planladığı görülmektedir. 
Meclis-i Mebusan'a giderek Ayan Reisi Hacı Adil Bey'le görüşen Murahhaslar, 8 Mart'ta Padişah V. Mehmed Reşad tarafından kabul edildi (Tasvir-i Efkâr, 9 Mart 1334/1918, n. 2388, s. 2). Görüşmede Enver Paşa da bulundu (Keykurun 104). Naki Bey, daha sonra "hidemât-ı hasenesine mebni" üçüncü rütbeden mecidî nişanı ile taltif edildi (BOA, i.DUiT, 67/90).

Kafkas murahhasları İstanbul basının da ilgisini çekiyordu. Tavsir-i Efkâr gazetesi Ömer Faik Bey ile 9 Mart günü bir mülakat gerçekleştirdi. Mülakat daha çok Kafkasya'nın askerî ve siyasî durumu hakkındaydı. Ömer Faik Bey, konuşmasında 1917 Mart ihtilali sonrasında Rusya'da kurulan hükümetler hakkında bilgi verdikten sonra ihtilallerin Kafkasya'yı nasıl etkilediği üzerinde durdu. Kafkasya'da kurulan hükümetin Ukrayna ve Finlandiya gibi her hususta serbestçe hareket ettiğini anlatan Ömer Faik Bey, yakın gelecekte her milletin kendi cumhuriyetini kuracağını belirtti. Ömer Faik Bey mülakatında ayrıca Kafkasya'da Müslümanlarla Gürcüler arasında önemli bir ihtilaf olmadığını, fakat asıl sorunun Ermenilerle olduğunu söyledi. Muhabirin "Kafkasya ordusu nasıl dağıldı?" sorusuna ise Kerenski hükûmetinin iktidara gelir gelmez bir grup askeri terhis ettiği, fakat Bolşeviklerin iktidara gelmesinden sonra merkezden terhis emrini beklemeden Rus askerlerinin Kafkas cephesini terk ettikleri cevabını verdi. "Brest-Litovsk'a gidecek yerde niçin buraya geldiniz?" sorusuna ise Ömer Faik Bey, Kafkasya barışının Brest-Litovsk'ta değil İstanbul'da olacağını söyleyerek artık Kafkasya üzerinde Osmanlı hükümetinin etkili olacağını ima ederek cevap verdi. Ömer Faik mülakatın çeşitli yerlerinde İstanbul'dan kesinlikle ümitli olduklarını belirtti (Tasvir-i Efkâr, 10 Mart 1334/1918, n. 2389, s. 1).

Kafkas murahhaslarının İstanbul'da Osmanlı yetkilileri ile temasları devam ediyorken Azerbaycan'da önemli gelişmeler meydana geldi. 30 Mart-2 Nisan tarihleri arasında Bakû'de Bolşevik ve Ermeni güçleri şehrin idaresini ele almak için büyük bir saldırı gerçekleştirdi. Çeşitli kaynaklarda "31 Mart Katliamı" olarak geçen bu saldırılarda, başta Bakû olmak üzere Lenkeran, Salyan, Kuba, Şemahı vb. şehirlerde binlerce Azeri sivilin öldürüldüğü kaydedilir. Yaşanan olaylarda

Bu tarih yine Kafkas murahhas heyetinin Suşehri'ne geldiği tarih ile örtüşmektedir. 
hayatını kaybedenlerin sayısı tartışma konusu olsa da, ${ }^{13}$ Azeriler açısından Bakû'nün Bolşevik ve Ermeni güçlerinden geri alınması ulusal bir dava haline gelmişti. Bakû'nün Bolşevik ve Ermeni güçlerinin eline geçtiği haberi İstanbul'a ulaştığında ise Kafkas İslam Ordusu teşkilatı hazırlıklarının hızlandığı aşikârdır. Çünkü Mart olaylarından sonra Karabağ Ermenileri, Bakû Bolşevikleriyle birleşme planları yapıyordu. Nitekim Bakû'deki Bolşevik yönetiminin gazetesi "muhtariyet değil harabezâr olacaksınız" diye yazıyordu (Resûlzâde 44). Bu şartlar altında Kafkas murahhaslarının İstanbul seyahatinin ve Osmanlı'dan temin edilecek yardımın önemi artmıştı.

İstanbul'daki çalışmalar sonunda Kafkas İslam Ordusu'nun Komutanı Nuri Paşa'nın kadrosu tamamlandı. Bir orduya komutanlık edecek olması nedeniyle Nuri Paşa'nın rütbesi yarbaylıktan fahri ferikliğe yükseltildi. Padişah V. Mehmed Reşad'ın kendisine verdiği fermanda Kafkas Müslümanlarına askerî ve siyasî hususlarda yardımcı olunması isteniyordu (Yüceer 72). Daha sonra Nuri Paşa ve ekibi Haydarpaşa Garı'ndan trenle Azerbaycan'a doğru yola çıktı. Kafkas İslam Ordusu'nun kuruluşu tamamlandıktan sonra Naki Bey'in artık İstanbul'da işi kalmamıştı. Nitekim Enver Paşa Naki Bey'e Reşit Paşa vapuruyla Köstence'ye, oradan Romanya'daki Kolordu ile beraber Trabzon'a ve sonra da Batum'a geçeceğini bildirdi. Bunun dışında Enver Paşa, Naki Bey'den Kafkasya'ya döndüğünde Nuri Paşa ile çalışmasını istedi (Keykurun 104-106). Böylece Kafkas murahhaslarının İstanbul'daki faaliyetleri sona ermiş oldu.

Kafkasya'daki gelişmeler ise baş döndürücü hızla devam ediyordu. Osmanlı Devleti ile Maverâ-yı Kafkasya Seym'i arasında 14 Mart'ta Trabzon'da başlayan barış müzakereleri, Seym'in Brest-Litovsk Antlaşması'ndaki hükümleri kabul etmemesi üzerine 14 Nisan'da başarısızlıkla sonuçlandı. ${ }^{14} 14$ Nisan'da Seym Osmanlı Devleti'ne savaş ilan etse de Osmanlı ordusu karşında tutunamadı. Osmanlı birlikleri 14

${ }^{13}$ Ermeni güçlerinin gerçekleştirdiği saldırılardaki can kayıpları için 3.000, $10.000,11.000,12.000$ ve hatta $25-30.000$ rakamları telaffuz edilmektedir. Mart-Nisan olayları hakkında ayrıntılı bilgi için bkz: Afanasyan 51-52; Bal 113124; Swietochowski 154-162; Çay 243-252; Neciyev 69-76; Şahin 2002: 391395

${ }^{14}$ Trabzon Konferansları ile daha ayrıntılı bilgi için bkz: Şahin 2002: 311445. 
Nisan'da Batum'a girdiler (NA, FO, 248/ 1196/188; The Times, 18 Nisan 1918, n. 41767, s. 6; Tanin, 16 Nisan 1334/1918, n. 3358, s. 1; Sabah, 16 Nisan 1334/1918, n. 10207, s. 1) ve kısa zamanda Kars önlerine kadar geldiler (Allen ve Muratof 510). Bu gelişmeler üzerine 22 Nisan'da bağımsızlığını ilan eden Maverâ-yı Kafkasya Seymi (NA, AIR, 1/22282/209/74/2; The Transcaucasian Post, 2 Nisan 1919, n. 12, s. 3), Osmanlı Devleti ile yeniden barış masasına oturmak istedi (Dokumentı i Materyalı 222). Osmanlı yetkilileri Maverâ-yı Kafkasya'nın teklifini kabul etse de (Şahin 2002: 502) 24 Nisan'da Kars'ı da alan Osmanlı birlikleri (Dokumentı i Materyalı 251-253; Ati, 27 Nisan 1334/1918, n. 117; Tanin, 27 Nisan 1334/1918, n. 3369; The Times, 29 Nisan 1918, n. 41776, s. 8) yönünü 1878 sınırları ötesine çevirdi. Kısacası aynı yılın Mayıs ayında yapılması kararlaştırılan Batum Konferansı'nda Osmanlı Devleti'nin hedefinde artık sadece BrestLitovsk Antlaşması hükümlerinin Maverâ-yı Kafkasya tarafından kabul edilmesi olmayacaktı.

\section{Murahhasların Kafkasya'ya Dönüşü ve Kafkasya'da Son Durum}

Naki Bey, Enver Paşa'nın talimatı doğrultusunda Köstence'ye doğru yola çıktı. Köstence'ye vardıklarında, Kolordu'nun da bindiği vapur doğruca Batum'a gitti. O sıralarda Batum'da Osmanlı, Azeri, Ermeni ve Gürcü delegeleri tarafından barış görüşmeleri yapılmaktaydı. Batum'a çıkan Naki Bey, bir süre burada Azerî ve Osmanlı barış delegeleriyle görüştükten sonra buradan Nuri Paşa'yı karşılamak için Gence'ye gitti (Keykurun 107-113) ${ }^{15}$.

Batum'da Osmanlı Devleti ile Maverâ-yı Kafkasya delegeleri arasında 11 Mayıs'ta başlayan barış müzakerelerinde Osmanlı talepleri 1878 sınırlarını aşarak, Ahıska, Ahılkelek, Gümrü, Sürmeli vb. bazı bölgelerinin Osmanlı Devleti'ne verilmesi ile Maverâ-yı Kafkasya demiryollarının kullanımı gibi hususları içermekteydi. Bu talepler Maverâ-yı Kafkas delegeleri arasında şok etkisi yaptı. 11 Mayıs'ta yapılan oturumdan sonra herhangi bir resmî oturum gerçekleşmedi (Şahin 2002: 545-550). Barış müzakerelerinin sonuçsuz kalması üzerine Osmanlı birlikleri 15-16 Mayıs'ta Gümrü’yü işgal ederek ileri

15 Ömer Faik Bey'in İstanbul'dan Kafkasya'ya nasıl döndüğüne dair herhangi bir kayıt bulunamamıştır. 
harekâta devam ettiler (Kafkas Cephesi 511). Maverâ-yı Kafkasya Seymi bu zor durumdan kurtulmanın çarelerini aramaya başladı. Sonunda Almanların güdümüne giren Gürcüler, 26 Mayıs'ta Maverâ-yı Kafkasya Seymi'ni feshederek bağımsızlıklarını ilan ettiler. Bu gelişmeleri müteakiben 28 Mayıs'ta Azeriler ve 29 Mayıs'ta ise Ermeniler bağımsızlıklarını ilan ettiler. ${ }^{16}$ Batum'daki görüşmelere ise münferiden devam edildi. Sonunda 4 Haziran 1918'de Osmanlı delegeleriyle Azerbaycan, Gürcistan, Ermenistan ve Kuzey Kafkasya delegeleri arasında çeşitli antlaşmalar imzalandı. Bu antlaşmalarla Osmanlı Devleti'nin konferansın başındaki taleplerinin tamamını gerçekleşti. Ahıska ve Ahılkelek de dâhil, Müslümanların yoğunlukla yaşadığı bölgeleri kendi topraklarına katan Osmanlı Devleti, Maverâ-yı Kafkasya demiryollarının da kullanım hakkını elde etti. Böylece Kafkas İslam Ordusu'na Bakû harekâtı sırasında kolayca lojistik destek sağlanabilecekti. Bunun dışında Azerbaycan ve Kuzey Kafkasya'ya da askerî yardım sözü vermişti ${ }^{17}$. Artık savaş sonuna kadar Maverâ-yı Kafkasya'nın siyasî, askerî ve iktisadî hayatına Osmanlı Devleti yön verecekti.

Osmanlı Devleti, vakit kaybetmeden Batum Antlaşması'yla kendisine verilen yerlerden Ahıska ve Ahılkelek'i işgal etti (Kafkas Cephesi 524). Böylece 1829 'da Edirne Antlaşması ile kaybedilen Ahıska ve Ahılkelek tekrar Osmanlı topraklarına dâhil edildi. Elviye-i Selâse'ye gönderilen Dâhiliye Nezareti Müsteşarı Abdülhalik (Renda) tarafından bölgenin ilhak çalışmaları başlatıldı. Böylece Ömer Faik Numanzâde'nin İstanbul'da Osmanlı yetkililerine Ahıska ve Ahılkelek'in ilhak edilmesi talebi yerine getirilecekti. Fakat Osmanlı Devleti Elviye-i Selâse'yi 15 Ağustos'ta ilhak etmesine rağmen ${ }^{18}$, Ahıska ve Ahılkelek'i ilhak etmedi. Bunun nedenlerinden birisi de Abdülhalik Bey tarafından Gümrü, Ahıska, Ahılkelek ve Sürmeli sancakları hususunda 22 Ağustos tarihinde Dâhiliye Nezareti'ne gönderilen rapordu. Abdülhalik Bey raporunda 1878 sınırları

\footnotetext{
${ }^{16}$ Ayrıntılı bilgi için bkz: Sarı 136-139.

17 Batum Konferansı'nın son safhası ve konferansta imzalanan antlaşmaların ayrıntıları bilgi için bkz: Şahin 2002: 606-640.

18 ilhak beyannamesi için bkz. BOA, DH/i-UM, n. 20-19/13-41, lef: 15; BOA, i.DUiT, n. 1/ 1, lef: 2; ikdam, 17 Ağustos 1334/1918, n. 7729, s. 2.
} 
ötesindeki yerlerin ilhak edilmesinin mahzurları üzerinde durmaktaydı (BOA, BEO.NGG, 339891).

İstanbul'dan Nisan ayı başında ayrılan Nuri Paşa Musul, Tebriz yoluyla 25 Mayıs'ta Azeriler tarafından büyük coşkuyla karşılandığı Gence'ye girdi. Nuri Paşa hemen burada karargâhını kurarak (Türker 8), gönüllülerden oluşan bir ordu oluşturmaya başladı. Bakû'yü almaya yeterli görülmeyen Kafkas İslam Ordusu'na takviye olarak 5. Kafkas Fırkası da gönderildi (Kafkas Cephesi 556). Hazırlıklarını tamamlayan Nuri Paşa hemen Bakû harekâtına başladı ve Osmanlı birlikleri sırasıyla 20 Haziran'da Gökçay'ı, 6 Temmuz'da Aksu'yu (Belen 175), 16/17 Temmuz'da Kurdemir'i (NA, WO, 106/6239; FO, 3371/ 3335, 130177; Yüceer 90), 20 Temmuz'da Şamahı'yı alarak 30 Temmuz'a kadar Akbulak ve Sumgayıt'a kadar ilerlediler (Belen 176). Bu gelişmelerden sonra Nuri Paşa, Bakû şehrini almak için 1 Ağustos'ta taarruz emrini vermesine rağmen Osmanlı birlikleri başarılı olamayarak 5 Ağustos'ta geri çekildi (Türker 126-135). Kafkas İslam Ordusu'nun takviye birliklerine ihtiyacı olduğu anlaşılmıştı.

Osmanlı birliklerinin ilk Bakû taarruzu başarısız olsa da bunun arkasının geleceğini iyi bilen Bakûlüler İngilizlerden askerî yardım istediler (Hovannisian 221). Bolşeviklerin itirazlarına rağmen Bakû'nün Osmanlı ya da Almanların eline geçmesini istemeyen İngilizler (Boston Daily Globe, 16 Ağustos 1918, s. 1), şehre İran'da bulunan Dunsterville komutasında birlikler gönderdiler (Hovannisian 221). Kafkas İslam Ordusu ise Romanya'dan gelen 15. Piyade Fırkası ile takviye edilmişti. Nuri Paşa birliklerine Bakû taarruzuna hazırlanmaları emrini verdi (Süleyman İzzet 36). Sonunda Osmanlı birlikleri Bakû'yü almak için 14 Eylül sabahı taarruza başladılar ve 15 Eylül'de şehre girdiler ${ }^{19}$. Bu başarıdan sonra Gence'de bulunan Azerbaycan hükümeti Bakû'ye nakledildi (ATASE, BDH, K: 3192, D: 114, B: 40).

Böylece Osmanlı ordusunun desteği ile Azerbaycan'ın toprak bütünlüğü sağlanmış ve bağımsızlığı teyit edilmiş, Osmanlı Devleti'nin Batum Konferansı'nda Azerilere verdiği yardım sözü de yerine gelmiş oldu. Fakat Osmanlı Devleti'nin aynı konferansta Kuzey Kafkasya halklarına da sözü vardı. Bu nedenle Osmanlı ordusu bu kez yönünü

${ }^{19}$ Kafkas İslâm Ordusu'nun Bakû'yü alması hakkında detaylı bilgi için bkz: Yüceer 116-122. 
kuzeye çevirerek 6 Ekim'de Derbent'i (Berkuk 64-68.), 8 Kasım'da da Petrovsk'u ele geçirdi (Kafkas Cephesi 617). Fakat bu zaferler kalıcı olmadı. Çünkü henüz Mondros Mütarekesi imzalanmadan, 21 Ekim 1918'de Osmanlı birliklerinin Kuzey Kafkasya, Azerbaycan, hatta Ahıska ve Ahılkelek gibi Brest-Litosvk Antlaşması dâhilinde olmayan yerlerden tahliyesi emri gelmişti (ATASE, iSH, K: 267, G: 101, B: 1011a). Mondros Mütarekesi ile de bu tahliye hızlanacaktı.

\section{Sonuç}

1917 yılında Rusya'da meydana gelen ihtilaller bütün dünyayı etkilediği gibi Kafkasya bölgesini de etkiledi. Rusya'da 1917 Mart ayında kurulan Geçici Hükümet'in aksine Kasım ayında iktidara gelen Bolşevikler, barış yönünde temayül gösterince Brest-Litovsk ve Erzincan Mütarekeleri imzalandı ve Rus birlikleri Doğu Anadolu'da işgal ettikleri toprakları ve Kafkasya'yı tahliye etmeye başladılar. Rus Ordu'sundan geri kalan silah, mühimmat ve savaş malzemeleriyle Gürcü ve Ermeni milli orduları kurulmaya başladı. Bu arada Bolşeviklerin ve Osmanlı Devleti'nin bölgeye tesir etmesini istemeyen Ingiltere ve Fransa da Gürcü ve Ermeni güçlerinin organize olmalarına yardım ettiler. Böylece teşkilatlarını belli ölçüde tamamlayan Gürcü ve Ermeni güçleri, Maverâ-yı Kafkasya'da Müslümanların çoğunlukta olduğu bölgeleri kontrol altına almak için harekete geçtiler. Bunun dışında Bakû'de Bolşevik ve Ermeniler etkili olmaya çalışmaktaydılar. Başta Azerbaycanlılar olmak üzere bölgenin Müslüman ve Türk halkları bu kıskaçtan kurtulmanın çarelerini aramaya başladılar ve sonunda Osmanlı Devleti'nden askerî ve siyasî yardım istemeye karar verdiler.

Ocak 1918 ortalarında aldıkları bir karar ile Azeriler Naki Keykurun Şeyhzamanlı'yı, Hüsamettin Bey ile birlikte Osmanlı'nın yardımını temin etmek için İstanbul'a gönderdiler. Bundan bağımsız olarak Ahıska Müslümanları adına Ömer Faik Numanzâde, Acara Müslümanları adına Hamşizâde Cemal Paşa'nın oğlu Celil Bey ve Ahılkelek Müslümanları adına da Efrahim Bey aynı maksatla İstanbul'a gittiler.

Hüsamettin Bey'in III. Ordu Komutanı Vehib Paşa'ya verdiği rapor, Ömer Faik Bey'in Enver ve Talat Paşalara gönderdiği mektup ve murahhasların İstanbul'daki Osmanlı yetkilileri ile görüşmeleri 
sonucunda 12 Şubat 1918 tarihinde başlayan Osmanlı ileri harekâtının şekli değişmişti. Osmanlı yetkilileri bu temaslarla Kafkasya'da Rus ordusunun kalmadığını, bölgede otorite boşluğunun bulunduğunu, Gürcü ve Ermeni silahlı güçlerinin teşkilatlanmasına meydan vermeden bir an önce kesin darbenin vurulması gerektiğini öğrenmişlerdir. Kafkas cephesi hakkında çok az malumatı bulunan Osmanlı yetkilileri için bu bilgiler oldukça önemli ve değerliydi. Bu bilgiler doğrultusunda kış şartlarına rağmen Osmanlı ileri harekâtı hızla devam etmiş, ilk önce I. Dünya Savaşı'nda Rusya'nın işgal ettiği topraklar geri alınmış, ardından Elviye-i Selâse ve hatta 1829 'da kaybedilen Ahıska, Ahılkelek vb. Müslümanların ve Türklerin meskûn olduğu topraklar işgal edilmiştir.

Kafkas murahhaslarının İstanbul'daki temasları doğrultusunda Osmanlı yetkilileri Ahıska ve Ahılkelek'i ilhak etmeyi düşünürken Azerbaycan toprakları için bunu düşünmemiştir. Çünkü Kafkas murahhaslarından Naki Keykurun şiddetle bağımsızlığı savunurken, Ömer Faik Numanzâde ise Ahıska ve Ahılkelek'in Osmanlı Devleti tarafından ilhak edilmesini talep etmekteydi.

Kafkas murahhas heyetinin İstanbul seyahatinin diğer bir sonucu ise Kafkas İslam Ordusu teşkilatının kurulması olmuştur. Naki Keykurun'un Enver Paşa ile görüşmeleri neticesinde Ordu komutanlığına Nuri Paşa getirilmiş ve teşkilat çalışmalarına da Naki Bey bizzat iştirak etmiştir. Nuri Paşa ise istanbul'da teşkilatını tamamladıktan sonra Azerbaycan'a giderek, yerel birliklerle birlikte Bakû ve Dağıstan'ın Osmanlı ordusu tarafından ele geçirilmesinde etken olmuştur.

Son olarak, Kafkas murahhaslarının III. Ordu karargâhının bulunduğu Suşehri'nde ve İstanbul'da Osmanlı yetkilileri ile gerçekleştirdiği görüşmeleri ve faaliyetleri, Kafkasya cephesinin kaderini doğrudan etkilemiştir. 


\section{KAYNAKÇA}

\section{ARŞiVLER}

ATASE (Genelkurmay Askerî Tarih ve Stratejik Etüt Dairesi Bşk.lığı Arşivi)

BDH (Büyük Dünya Harbi)

isH (İstiklal Harbi)

BOA (Başbakanlık Devlet Arşivleri Genel Müdürlüğü Osmanlı Arşivi)

DH.ŞFR (Dâhiliye Nezareti Şifre Kalemi)

DH.EUM.5. Şb (Dâhiliye Nezareti Emniyet-i Umumiye Müdüriyeti 5. Şube)

DH/i-UM (Dâhiliye Nezareti İdare-i Umumiye Evrakı)

I.DUiT (Dosya Usulü İrade Tasnifi)

BEO.NGG (Babıâli Evrak Odası Nezaret Gelen Giden)

\section{NA (The National Archives of United Kingdom/İngiliz Millî Arşivleri)}

WO (War Office)

FO (Foreign Office)

AIR (Air Force)

\section{BASILI BELGELER}

Düstur, Tertib-i Sânî, c. X, Evkaf Matbaası, İstanbul, 1928

Dokumentı i Materyalı Po Vneşney Zakavkazya i Gruzii, Tipografiya Pravitelstva Gruzinskoy Respubliki, Tiflis, 1919.

Dokumentı Vneşney Politiki SSSR, C. I, Gosudarstvennoe İzdatelstvo Politiçeskoy Literaturı, Moskva, 1957.

Meclis-i Mebusan Zabıt Cerideleri, Devre: 3, İçtima Senesi: 4, c. III, , T.B.M.M. Basımevi, Ankara, 1991.

\section{SÜRELI YAYINLAR}

\section{Ati}

Boston Daily Globe

ikdam

Tanin

Sabah

Tasvir-i Efkâr

The Transcaucasian Post

The Times

The Manchester Guardian 


\section{MAKALE VE KITAPLAR}

Afanasyan, S. (1981), L'Arménie L'Azerbaidjan Et La Géorgie De L'Indépendance à L'Instauration Du Pouvoir Soviétique (1917-1923), Paris.

Allen, W. E. D. ve Muratoff P. (1966), Kafkas Harekâtı (1828-1921): TürkKafkas Sınırındaki Harplerin Tarihi, Genelkurmay Basımevi: Ankara.

Aslan, B. (2000), I. Dünya Savaşı Esnasında Azerbaycan Türklerinin Anadolu Türklerine Kardaş Kömeği (Yardımı) ve Bakû Müslüman Cemiyet-i Hayriyesi, Atatürk Kültür Merkezi Başkanlığı Yayınları: Ankara.

Atak, M. S. (1953), Doğunun Kilidi Aras, Güzel İstanbul Matbaası: İstanbul.

Bal, H. (2010), Azerbaycan Cumhuriyeti'nin Kuruluş Mücadelesi ve Kafkas islam Ordusu, İdil Yayıncılık: İstanbul.

Belen, F. (1967), Birinci Cihan Harbinde Türk Harbi 1918 Yılı Hareketleri, c. V, Genelkurmay Basımevi: Ankara.

Berkuk, i. (1334), Büyük Harpte, Şimalî Kafkasya'daki Faaliyetlerimiz ve 15. Fırkanın Harekâtı ve Muharebeleri (Eylül 1934), Askeri Matbaa: İstanbul.

Birinci Dünya Harbinde Türk Harbi: Kafkas Cephesi 3 üncü Ordu Harekâtı, (1993), 2/2, Genelkurmay Basımevi: Ankara.

Çakmak, F. (1936), Büyük Harpte Şark Cephesi Hareketleri, Genelkurmay Matbaası: Ankara.

Çay, A. (1985), “Ermenilerin Bakü'de Yaptığı 31 Mart 1918 Katli'âmı”, Tarih Boyunca Türklerin Ermeni Toplumu ile ilişkileri Sempozyumu, Atatürk Üniversitesi Yayınları: Ankara.

Hovannisian, R. G. (1967), Armenia on the Road to Independence 1918, University of California Press: Berkeley, Los Angeles.

Karabekir, K. (1990), Erzincan ve Erzurum'un Kurtuluşu Sarıkamış, Kars ve Ötesi, Erzurum Ticaret ve Sanayi Odası Yayınları: Erzurum.

Karabekir, K. (2009), Günlükler (1906-1948), C. I, Yay.Haz. Yücel Demirel, Yapı Kredi Yayınları: İstanbul.

Kazemzadeh, F. (1951), The Struggle For Transcaucasia (1917-1921), Philosopohical Library: New York, George Ronald, Oxford.

Keykurun, N. (1998), Azerbaycan Istiklal Mücadelesinin Hatıraları: 19051920, ilke Kitapevi: Ankara.

Kılıç, S. (1998), Türk-Sovyet Iliş̧ilerinin Doğuşu, Brest-Litovsk Barışı ve Müzakereleri (22 Aralık 1917 - 3 Mart 1918), Ülke Yayınları: İstanbul.

Kırpık, C. (2010), “II. Meşrutiyet'ten Sonra Şehzade Eğitiminde Değişim”, SDÜ Fen Edebiyat Fakültesi Sosyal Bilimler Dergisi, 21, 99-130.

Kurat, A. N. (1990), Türkiye ve Rusya, Türk Tarih Kurumu Yayınları: Ankara.

Kurat, A. N. (1967), “Brest-Litovsk Müzakereleri ve Barışı (20 Aralık 1917-3 Mart 1918)", Belleten, 31/123, Türk Tarih Kurumu Basımevi: Ankara, 375413. 
Mehmetzâde, M. B. (1938), Millî Azerbaycan Hareketi, Millî Azerbaycan "Müsavat" Halk Fırkası Tarihi, Berlin.

Neciyev, E. (2006), Kafkaslarda Türk Katliamı, Emre Yayınları: İstanbul.

Numanzade, Ö. F. (2000), Kafkasya'dan Istanbul'a Hatıralar, Haz. İran Murat Yıldırım, Fazıl Gökçek, Akademi Kitapevi: İzmir.

Qafarov, V. (2011), Türkiye-Rusya Münasebetlerinde Azerbaycan Meselesi (1917-1922), Azerneşr: Bakı.

Resûlzâde, M. E. (1990), Azerbaycan Cumhuriyeti, Keyfiyet-i Teşekkülü ve Şimdiki Vaziyeti, Yay. Haz. Yavuz Akpınar v.d., Azerbaycan Türkleri Kültür ve Dayanışma Derneği Yayınları: İstanbul.

Sarı, M. (2014), Türkiye-Kafkasya Ilişkilerinde Batum (1917-1921), Türk Tarih Kurumu Yayınları: Ankara.

Süleyman i. (1936), Büyük Harpte (1334-1918) 15. Piyade Tümeninin Azerbaycan ve Şimalî Kafkasya'daki Hareket ve Muharebeleri, Askerî Matbaa: İstanbul.

Süleymanov, M. (2008), “Kafkas İslam Ordusu'nun Kuruluşu, Hazırlık ve Seferberlik Durumu", Kafkas islam Ordusu ve Azerbaycan Halk Cumhuriyeti'nin Oluşumu, edt. Mehmet Rıhtım, Mehman Süleymanov, Atatürk Üniversitesi Yayınları: Bakü, 205-260.

Swietochowski, T. (1988), Müslüman Cemaatten Ulusal Kimliğe Rus Azerbaycanı 1905-1920, Çev. Nuray Mert, Bağlam Yayınları: İstanbul.

Şahin, E. (1998), “Türkiye Maverâ-yı Kafkasya Komiserliği IIlişkilerinin Başlaması ve Erzincan Mütarekesi", Kafkas Araştırmaları, 4, İstanbul, 169171.

Şahin, E. (2002), Türkiye ve Maverâ-yı Kafkasya Iliş̧kileri İ̧̧erisinde Trabzon ve Batum Konferansları ve Antlaşmaları (1917-1918), Türk Tarih Kurumu Yayınları: Ankara.

Şükürov, Q. (2010), “Cumhuriyetin Kuruluş Devrinde Azerbaycan'da İstiklâl ve illhak Tartışmaları", Büyük Devletler Kıskacında Bağımsız Azerbaycan (1918-1920), edt. Qiyas Şükürov, Vasif Qafarov, IQ Kültür Sanat Yayıncılık: İstanbul, 38-72.

Tugaç, H. (1975), Bir Neslin Dramı: Kafkas Cephesinden Çarlık Rusyası'nda Tutsaklıktan Anılar, Çağdaş Yayınları: İstanbul.

Yüceer, N. (1996), Birinci Dünya Savaşı'nda Osmanlı Ordusu'nun Azerbaycan ve Dağıstan Harekâtı Azerbaycan ve Dağıstan'ın Bağımsızlığını Kazanması 1918, Genelkurmay Basımevi: Ankara. 
EK

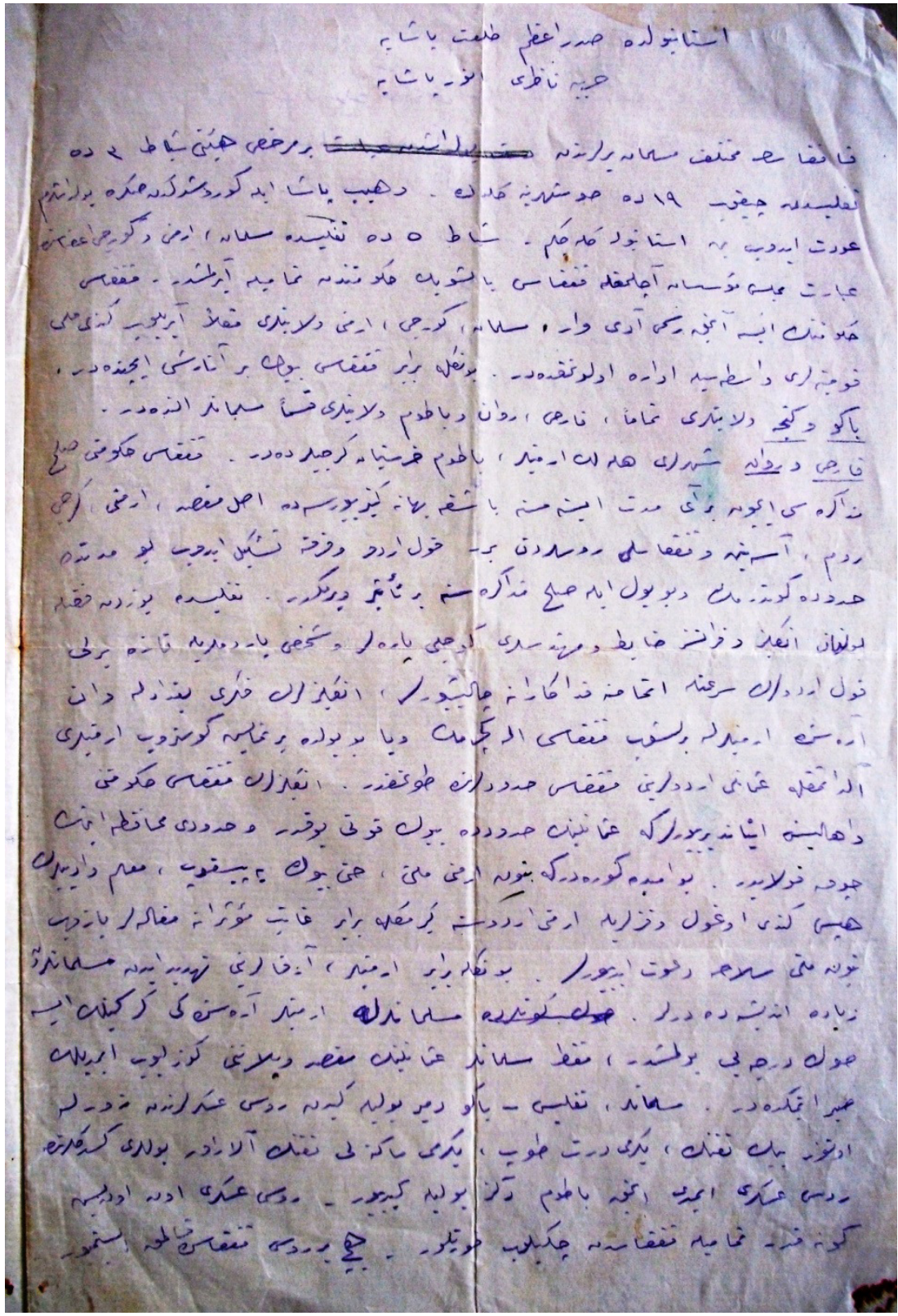

Ömer Faik Numanzade'nin Talat Paşa'ya ve Enver Paşa'ya gönderdiği mektup (BOA, DH.EUM.5.Şb., no. 55/26) 
